\title{
Amended Description of the Genus Xenorhabdus Thomas and Poinar
}

\author{
GERARD M. THOMAS* AND GEORGE O. POINAR, JR. \\ Department of Entomology and Parasitology, University of California, Berkeley, California
}

\begin{abstract}
Bacteria symbiotically associated with entomogenous nematodes were described and placed in the genus Xenorhabdus in 1979. Since that time, additional studies on members of the genus, the designation of the new subspecies Xenorhabdus nematophilus subsp. nematophilus and $X$. nematophilus subsp. bovienii, the description of a new strain of $X$. nematophilus subsp. poinarii, and the observation of colonial dimorphism in members of the genus have brought about the necessity for an amended description. The description of the genus Xenorhabdus is amended to include dimorphism and additional characteristics.
\end{abstract}

In 1979, the genus Xenorhabdus Thomas and Poinar (4) was erected in the family Enterobacteriaceae to contain the unique bacteria that are symbiotically associated with entomogenous nematodes of the genera Neoaplectana and $\mathrm{He}$ terorhabditis. Two species, Xenorhabdus nematophilus (Poinar and Thomas) and Xenorhabdus luminescens Thomas and Poinar were placed in this genus (4). Since that time, another bacterium significantly different from these two species has been found in association with the nematode Neoaplectana glaseri Steiner, and this bacterium was described by Akhurst (2) as $X$. nematophilus subsp. poinarii. In the same paper, Akhurst further designated the bacterial symbionts of Neoaplectana carpocapsae $(=$ Neoaplectana feltiae) as $X$. nematophilus subsp. nematophilus and the bacterial symbionts of Neoaplectana bibionis as $X$. nematophilus subsp. bovienii. In addition, Akhurst (1) has observed dimorphism in Xenorhabdus. Colonial dimorphism in members of Xenorhabdus and the characteristics of $X$. nematophilus subsp. poinarii necessitate an amended description of the genus Xenorhabdus, which is presented in this paper.

Amended description of Xenorhabdus Thomas and Poinar. Gram-negative, asporogenous, peritrichous rods varying from 0.3 to $1.9 \mu \mathrm{m}$ wide and from 2.3 to $21.9 \mu \mathrm{m}$ long (average, 1.0 by 5.8 $\mu \mathrm{m})$. Motile. In older cultures, crystalline inclusions (which are not poly-beta-hydroxybutyrate) are formed within the cells; spherical cells, resulting from the disintegration of the cell wall, average $2.6 \mu \mathrm{m}$ in diameter. Facultatively anaerobic. Nutrition is chemoorganotrophic; good growth occurs on meat extract and simple peptone agar. Metabolism is respiratory and fermentative. Acid, usually without gas, is produced from the fermentation of glucose, fructose, maltose, mannose, and ribose (2). Variable production of acid is obtained from cellobiose, glycerol, inositol, melezitose, $\alpha$ methylglucoside, saccharose, salicin, sorbitol, sucrose, trehalose, and xylose (2). Starch is not hydrolyzed.

The primary form is the form normally carried by infective-stage nematodes and transmitted into host insects. Akhurst (1) has reported that the primary form also provides better conditions for reproduction of the nematodes in the hosts than the secondary form does. In addition, the secondary form, which is produced on agar media, is usually stable, whereas the primary form tends to be unstable in culture. However, there appears to be no significant difference in entomopathogenicity between the two forms (1).

Colonies of primary forms of $X$. nematophilus subsp. nematophilus, $X$. nematophilus subsp. bovienii, and $X$. nematophilus subsp. poinarii on nutrient agar are about $1 \mathrm{~mm}$ in diameter after 24 to $48 \mathrm{~h}$ at $24^{\circ} \mathrm{C}$; they may be smooth, moist, slightly mucoid, and somewhat granular in appearance. In addition, the colonies are low convex, circular with slightly irregular margins, and grayish, cream colored $(X$. nematophilus subsp. nematophilus), yellowish brown ( $X$. nematophilus subsp. bovienii), or rust brown to reddish ( $X$. nematophilus subsp. poinarii). Colonies of secondary forms differ in being somewhat translucent and flatter with spreading margins and less pigmentation.

Primary colonies of $X$. luminescens on nutrient agar are more mucoid and more intensely pigmented than secondary forms. The latter also produce flatter colonies with spreading margins. Both forms are luminescent, but the primary form appears to be more strongly luminescent than the secondary form, although this has not been measured photometrically.

On tergitol-7 agar supplemented with $0.04 \mathrm{mg}$ of triphenyltetrazolium chloride per liter young colonies ( 24 to $48 \mathrm{~h}$ old) of primary forms of $X$. 
nematophilus subsp. nematophilus, $X$. nematophilus subsp. bovienii, and $X$. luminescens strains are gray, but as the colonies age, bromothymol blue is absorbed from the medium and combines with pigments produced by the bacteria, causing the colonies to take on a characteristic coloration. $X$. nematophilus subsp. nematophilus colonies become blue to deep purple, $X$. nematophilus subsp. bovienii colonies become greenish to blue green, and $X$. luminescens colonies become greenish with reddish brown centers. In all of the above strains, absorption of the bromothymol blue results in clearing zones in the agar surrounding the colonies. Secondary forms of the taxa described above do not absorb the bromothymol blue, the colonies take on various shades of red to rust, and clearing zones do not develop. Neither the primary nor secondary forms of $X$. nematophilus subsp. poinarii absorb the bromothymol blue from tergitol-7 agar supplemented with $0.04 \mathrm{mg}$ of triphenyltetrazolium chloride per liter. Consequently, clearing zones do not develop, and the colonies become red to rust in color. Secondary forms of all species tend to produce flatter colonies with spreading and translucent margins.

Glutamic acid, lysine decarboxylase, ornithine decarboxylase, arginine dihydrolase, oxidase, and cytochrome oxidase are not produced. Urease is not produced by $X$. nematophilus subsp. nematophilus, $X$. nematophilus subsp. bovienii, or $X$. nematophilus subsp. poinarii, but is produced by $X$. luminescens (2). The methyl red and Voges-Proskauer tests are negative. Indole is not produced by $X$. nematophilus subsp. nematophilus, $X$. nematophilus subsp. bovienii, or $X$. nematophilus subsp. poinarii. However, Akhurst (2) found indole production in $X$. luminescens to be variable. Hydrogen sulfide (triple sugar iron agar) is not produced. Nitrates are not reduced to nitrites. Production of lipase and phenyalanine deaminase is variable (2). Citrate is generally not utilized in Simmons citrate agar, but is utilized on OY medium (2), as described by Dye (3). Tests for proteolysis by using Loeffler blood serum agar and nutrient gelatin have produced variable results $(2,4)$. Catalase may or may not be produced, but even apparently negative strains may occasionally show weakly positive results.

The guanine-plus-cytosine content of the deoxyribonucleic acid is 43 to $50 \mathrm{~mol} \%$ (2). Species of $X$. nematophilus and $X$. luminescens are immunologically distinct from marine luminescent bacteria, as well as from members of the genera Escherichia, Enterobacter, Serratia, Proteus, and Aeromonas (Paul Baumann, personal communication).

The natural habitats for these bacteria are the intestinal lumina of entomogenous nematodes and the body cavities of infected host insects.

The type species is Xenorhabdus nematophilus (Poinar and Thomas), and the type strain of this species is strain ATCC 19061.

\section{LITERATURE CITED}

1. Akhurst, A. J. 1980. Dimorphism in Xenorhabdus spp., bacteria symbiotically associated with the insect pathogenic nematodes Neoaplectana and Heterorhabditis. J. Gen. Microbiol. 121:303-309.

2. Akhurst, A. J. 1983. A taxonomic study of Xenorhabdus, a genus of bacteria symbiotically associated with insectpathogenic nematodes. Int. J. Syst. Bacteriol. 33:38-45.

3. Dye, D. W. 1968. A taxonomic study of the genus Erwinia. I. The "amylovora" group. N. Z. J. Sci. 11:590-607.

4. Thomas, G. M., and G. O. Poinar, Jr. 1979. Xenorhabdus gen. nov., a genus of entomopathogenic, nematophilic bacteria of the family Enterobacteriaceae. Int. J. Syst. Bacteriol. 29:352-360. 